\title{
IJPHN
}

\section{The Differences of Haemoglobin changes between two methods of IFA Supplementations among Anemic Female Adolescent Students of Miftahul Huda Al Azhar Langgensari Islamic Boarding School, West Java}

\author{
Syabilila Indraswari ${ }^{1}$ *, Endang L Achadi ${ }^{2}$ \\ ${ }^{1}$ Magister Program of Public Health Nutrition, Faculty of Public Health Universitas Indonesia \\ ${ }^{2}$ Depatment of Public Health Nutrition, Faculty of Public Health, Universitas Indonesia, F Building $2^{\text {nd }}$ \\ Floor Kampus Baru UI Depok 16424, Indonesia \\ *Corresponding Author: \\ Syabilila Indraswari \\ E-mail: syabilila.Indraswari@gmail.com
}

\begin{abstract}
Female adolescent students in boarding schools are vulnerable in having anemia due to packed schedule and limited animal source food. The aim of this research was to compare the differences of haemoglobin level after weekly Iron Folate Acid (IFA) tablet supplementation and weekly plus daily IFA tablet supplementation during menstruation for 8 week of intervention among anemic students. This study used quasi experimental non equivalent control group design. A total of 40 anemic respondents was selected in this study, 20 of them received a weekly IFA tablet supplementation (treatment 1 group), and the 20 other respondents received weekly plus daily during their menstruation (treatment 2 group). The first hemoglobin measurement and other variables were obtained prior to intervention. Around 52\% of all 278 eligible students were anemic at the start of the study. Of the anemic selected sample, 2 of them left the boarding school in the middle of the study because they were ill. At the end the study 23 out of 38 anemic samples $(60.5 \%)$ became non anemic. There was a significant increase of haemoglobin level in both groups after the intervention (both groups have $\mathrm{p}$ value $<0.01$ ). This increase was not significantly different between the two interventions $(p=0.797)$. This study proved that weekly supplementation was as effective as weekly plus daily supplementation during menstruation in increasing Haemoglobin $(\mathrm{Hb})$ level among anemic students.
\end{abstract}

Key words: Anemia, Adolescent, IFA supplementation

\begin{abstract}
Abstrak
Santri remaja putri rentan terkena anemia karena kegiatan yang padat dan kurangnya asupan zat gizi terutama makanan sumber pangan hewani. Penelitian ini dilakukan untuk mengetahui perbandingan antara dua program suplementasi tablet tambah darah yang terdiri dari zat besi dan asam folat (TTD), yaitu yang diberi satu tablet per minggu (group perlakuan 1) dan yang diberi satu tablet per minggu ditambah satu tablet sehari saat menstruasi selama 8 minggu (group perlakuan 2). Penelitian ini menggunakan disain quasi experimental nonequivalent control group. Responden penelitian ini sebanyak 38 orang dimana 20 orang menerima suplementasi mingguan ( 2 orang kemudian meninggalkan pondok saat penelitian karena sakit) dan 20 orang menerima suplementasi ming guan ditambah setiap hari saat menstruasi. Pengukuran data pengetahuan, menstruasi, status gizi, pola konsumsi inhibitor, enhancer dan protein hewani dilakukan sebelum intervensi, data suplementasi diukur setelah intervensi dan data kadar hemoglobin diukur saat sebelum dan sesudah intervensi. Pemeriksaan Hb pertama terhadap semua 278 siswa, sekitar 52\% menderita Anemia. Diantara sampel siswa yang anemia, pada akhir intervensi 60.5\% nya menjadi tidak anemia. Terjadi kenaikan kadarhemoglobin pada kedua kelompok setelah intervensi selama 8 minggu (kedua grup mempunyai nilai $\mathrm{p}<0.01$ ). Kenaikan tersebut tidak berbeda antara kedua kelompok perlakuan $(p=0,797)$. Hasil penelitian ini membuktikan bahwa suplementasi mingguan pada siswa yang menderita anemia memberikan efektivitas yang sama dalam meningkatkan kadar hemoglobin $(\mathrm{Hb})$ darah dengan suplementasi ming guan ditambah harian selama menstruasi.
\end{abstract}

Kata kunci: Anemia, Remaja, Suplementasi TTD 


\section{Introduction}

Globally, anemia affect about one fourth of the world's population, and most of them are caused by iron deficiency (1). Anemic female adolescents are at risk of becoming anemia when they became pregnant which can give serious impacts on the growth of their babies (2) (3). The prevalence of anemia in the female students in many regions in Asia is around $17-90 \%$, while the prevalence of iron depletion and iron deficiency were higher than iron deficiency anemia prevalence itself (4). If the problem is not overcome soon, then the subjects who are in the state of iron depletion and deficiency would be easily become iron deficiency anemia (4).

The high level of anemia prevalence among female adolescents is caused by the increased need of iron when they experience growth spurt in their adolescence. In this time period, their sexual maturity is developing and they become more mature because of the function of endocrine which has become fully developed (5)(6). In addition, female adolescent are vulnerable in getting anemia because they lose blood during their periods. Women tend to have lower amount of iron reserve compared to men, and this can cause them to be more vulnerable in having deficiency when their intake for iron is inadequate. Female adolescents who are in their period will lose blood once in a month so they need iron twice as much in their period time (7) (8).

Based on the research by Hamidiyah et al (2019) held in Situbondo, the prevalence of anemia in female students in boarding schools was $79 \%$ (9). The female students are vulnerable to be anemic because their daily life in the boarding schools which do not allow them to live with their parents, as well as the tight schedules of their daily activities. These causes result to irregularity of their dietary habit and lack of quality nutritients (10) (11).

The objective of this study is to assess the difference in the level of hemoglobin by using two methods of supplementation program, between a one Iron Folate Acid (IFA) tablet per week supplement and once-in-a-week supplement plus daily supplement in their period time for 8 weeks. The subjects are the female students in Pondok Pesantren Miftahul Huda Al Azhar Langgensari Kota Banjar in West Java between January and March 2020.

\section{Methods}

The design used in this study was quasi experimental non equivalent control group design. Before the two groups were treated, there was a pre-test held to get the image of the starting condition before treatment and post-test was held after treatment. The study conducted in Pondok Pesantren Miftahul Huda Al Azhar Langgensari Kota Banjar in West Java Province for 8 weeks, started from January 2020 until March 2020. The samples were taken by using simple random sampling technique and after they were tabulated, 40 respondents were selected who were then divided into 2 groups, treatment 1 group and treatment 2 group. At the end of this study there were 2 respondents who dropped out because they were ill and sent home. The data was analysed using dependent and independent $t$-tests to determine the difference of $\mathrm{Hb}$ mean between the two groups, and Multiple Linear Regression analysis.

This study has passed through the ethical review and got its proper result, held by the Commission of Ethical Research and Public Health Service of the Universitas Indonesia 
under the number of: Ket13/UN2.F10.D11/PPM.00.02/2019.

\section{Results}

The initial screening of this study resulted in from all female adolescent who already had menstruation, $52.25 \%$ of them are anemic whereas $29.78 \%$ of them having mild anemia and $22.47 \%$ of them are having moderate anemia.

Most of the respondents are having enough knowledge, having normal BMI-for-Age (BAZ) and MidUpper Arm Circumference (MUAC) having their menstruation for $\leq 7$ days, using $<6$ menstrual pad in one of the hardest days in their menstrual cycle, not consuming inhibitor with their meals, less take of non-animal enhancer, also consuming $\mathrm{Fe}$ tablets more than 8, and all respondents $(100 \%)$ in this research have consumed the Fe tablets given to them. While for the duration of menarche and study is shown in the Table 3 where the average time of their menstruation with the study is 3.49 years with the deviation standard of 2.12 years.

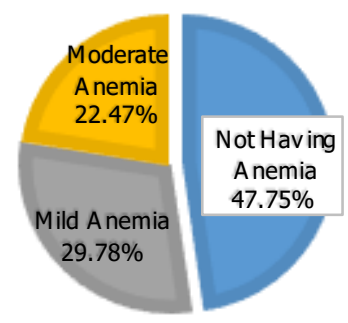

Figure 1. The Proportion of Ane mia among Female Students who already Menstruate in Miftahul Huda Al Azhar Boarding School $(\mathrm{n}=278)$

Table 1. The Frequency Distribution of Respondents' Variables

\begin{tabular}{|c|c|c|c|}
\hline Variables & & Frequency (n) & Percentage $(\%)$ \\
\hline \multirow{2}{*}{ Knowledge } & Less & 17 & 44.7 \\
\hline & Adequate & 21 & 55.3 \\
\hline \multirow{2}{*}{ Consumption of Fe Supplement } & $\leq 8 \mathrm{mg}$ & 18 & 47.37 \\
\hline & $>8 \mathrm{mg}$ & 20 & 52.63 \\
\hline \multirow[t]{2}{*}{ BAZ } & Normal & 29 & 76.3 \\
\hline & Over & 9 & 23.7 \\
\hline \multirow[t]{2}{*}{ MUAC } & $<18.5 \mathrm{~cm}$ & 3 & 7.9 \\
\hline & $>=18.5 \mathrm{~cm}$ & 35 & 92.1 \\
\hline \multirow[t]{2}{*}{ MenstrualCycle } & $\begin{array}{l}\text { Long (.>7 } \\
\text { days) }\end{array}$ & 16 & 42.1 \\
\hline & Short & 22 & 57.9 \\
\hline \multirow[t]{2}{*}{ Amount of Menstruation } & Plenty & 5 & 13.2 \\
\hline & Little & 33 & 86.8 \\
\hline \multirow[t]{2}{*}{ Consumption of Inhibitor with Meals } & Yes & 8 & 21.1 \\
\hline & No & 30 & 78.9 \\
\hline \multirow[t]{2}{*}{ Consumption of Non-Animal Enhancer } & Less & 30 & 78.9 \\
\hline & Adequate & 8 & 21.1 \\
\hline \multirow[t]{2}{*}{ Consumption of Animal-Based Protein } & Less & 31 & 81.6 \\
\hline & Adequate & 7 & 18.4 \\
\hline
\end{tabular}


Table 2. Distribution of Time between Menarche and the Study

\begin{tabular}{lc}
\hline Range between menarche and Study & Total \\
\hline Mean \pm SD & $3.49 \pm 2.12$ \\
Median & 3.11 \\
Minimum-Maximum & $0.17-8.45$ \\
$95 \%$ CI & $2.79-4.19$ \\
\hline
\end{tabular}

Table 3. Distribution of Hemoglobin level by Treatment Group

\begin{tabular}{|c|c|c|c|c|c|c|}
\hline Hb Level & Mean \pm SD & Median & $\begin{array}{l}\text { Min- } \\
\text { Max }\end{array}$ & $95 \% \mathrm{CI}$ & $\begin{array}{c}\mathrm{p} \text {-value } \\
\text { dependent } \mathrm{t}- \\
\text { test }\end{array}$ & $\begin{array}{c}\mathrm{p} \text {-value } \\
\text { independent t- } \\
\text { test }\end{array}$ \\
\hline Treatment 1 & & & & & 0.0005 & 0.797 \\
\hline Starting Level of $\mathrm{Hb}$ & $10.56 \pm 1.02$ & 10.8 & 8.6-11.9 & $10.05-11.06$ & & \\
\hline Final Level of $\mathrm{Hb}$ & $11.9 \pm 1.04$ & 12.00 & $9.7-13.7$ & $11.38-12.42$ & & \\
\hline Increasing & $1.34 \pm 0.89$ & 1.10 & $0.0-3.1$ & $0.90-1.79$ & & \\
\hline Treatment 2 & $10.79 \pm 0.81$ & 11.20 & $9.3-11.7$ & $10.42-11.17$ & 0.0005 & \\
\hline Starting Level of $\mathrm{Hb}$ & $12.07 \pm 0.84$ & 12.15 & $10.7-13.7$ & $11.67-12.46$ & & \\
\hline $\begin{array}{l}\text { Final Level of } \mathrm{Hb} \\
\text { Increasing }\end{array}$ & $1.27 \pm 0.88$ & 1.10 & $0.0-3.3$ & $0.86-1.68$ & & \\
\hline
\end{tabular}

Table 4. Distribution of Respondents based on Anemic Status before and after intervention in each Group

\begin{tabular}{lcccccc}
\hline \multirow{2}{*}{ Status of Anemia } & \multicolumn{2}{c}{ Treatment 1 } & \multicolumn{2}{c}{ Treatment 2 } & \multicolumn{2}{c}{ Total } \\
\cline { 2 - 7 } & $\mathrm{n}$ & $\%$ & $\mathrm{n}$ & $\%$ & $\mathrm{n}$ & $\%$ \\
\hline Before Treatment & & & & & & \\
$\quad$ Anemia & 18 & 100 & 20 & 100 & 38 & 100 \\
$\quad$ Not Anemia & 0 & 0 & 0 & 0 & 0 & 0 \\
\hline Total & 18 & 100 & 20 & 100 & 38 & 100 \\
\hline After Treatment & & & & & & \\
$\quad$ Anemia & 9 & 50,0 & 6 & 30,0 & 15 & 39,5 \\
$\quad$ Not Anemia & 9 & 50,0 & 14 & 70,0 & 23 & 60,5 \\
\hline Total & 18 & 100 & 20 & 100 & 38 & 100 \\
\hline
\end{tabular}

Table 5 Final Modeling of Multiple Linear Regression

\begin{tabular}{|c|c|c|c|}
\hline Independent Variables & p-value & Beta Coef & R Square \\
\hline Knowledge & 0.021 & 0.515 & 0.657 \\
\hline Consumption of Fe tablets supplement & 0.743 & 0.061 & \\
\hline MenstrualCycle & 0.003 & -0.633 & \\
\hline Inhibitor Consumption Pattern & 0.003 & -1.130 & \\
\hline Enhancer Consumption Pattern Non-Animal & 0.276 & 0.297 & \\
\hline Consumption Pattern of Animal-Based Protein & 0.0005 & 1.085 & \\
\hline
\end{tabular}

During the examination of the final hemoglobin, the average amount of hemoglobin in each group increased. The treatment 1 group, $\mathrm{Hb}$ increased by $1.34 \mathrm{~g} / \mathrm{dL}$ with variation of $0.89 \mathrm{~g} / \mathrm{dL}$. While in the treatment 2 group group increased by $1.27 \mathrm{~g} / \mathrm{dL}$ with the variation of $0.88 \mathrm{~g} / \mathrm{dL}$.
The results of dependent t-test in the treatment 1 and treatment 2 is $\mathrm{p}=0.0005$ which means statistically there is a difference in the average rate of hemoglobin in the respondents after the supplement of IFA tablets both once in a week and once in a week plus in their menstrual cycle. The result of independent t-test is $\mathrm{p}=0.797$ which 
means that there are no significant difference between the two groups. At the end of the study, $60,5 \%$ of the

From the results of multivariate analysis, there are 6 from 10 variables which affect the increased level of $\mathrm{Hb}$ which are knowledge, consumption, and supplement of IFA tablets, menstrual cycle, inhibitor dietary habit, nonanimal enhancer, and the animal-based protein dietary habit which is shown by the biggest Coef $\mathrm{B}$ amount.

The final modeling for multivariate test showed that the $\mathrm{R}$ Square value was 0,657 , its mean the model can explain $65,7 \%$ the variation of increasing haemoglobin level. In other worlds, independen variables in the final modeling are able to explain dependen variabel around $65,7 \%$.

\section{Discussion}

In the preliminary screening of this study, there was $52.25 \%$ of the female students who are anemic, so it can be said that the problem of anemia in the Miftahul Huda Al Azhar Boarding School is a big problem where the prevalence reached $\geq 40 \%$.

The knowledge of most of the respondents $(55.3 \%$ ) about anemia and IFA tablets before treatment is considered enough, although all of the respondents are anemic. The status of nutrition based on BAZ from most of the respondents (76.3\%) is having normal nutrition status and $92.1 \%$ of the respondents have normal MUAC. The result of this study is in line with the study conducted by Shara, Wahid, \& Semiarti (2017), about anemia in the female adolescent in Sawahlunto, West Sumetera, where most of the respondents are having normal nutrition level. The result of the study shows that the respondents in this study are anemic but the nutrition level of the respondents are mostly normal, therefore further respondents changes the status into non anemia.

study should be conducted to know about the type and amount of meals consumed by the respondents, so that the quality of the meals can be known. The measurement of nutritional level is held in the anthropometry method which measure the weight and proportion of the body, mostly only showing the balance between macro nutrition (13). It will not be able to show the iron in the body, but by measuring the BAZ and MUAC can be used to analyze whether the body in the normal condition for $\mathrm{Fe}$ metabolism or not.

In this study, there are 16 respondents $(42.1 \%)$ which have the menstrual cycle longer than 7 days, this result is in line with the study conducted by Arumsari (2008), which studies the risk factors of anemia among female adolescent in Bekasi. It is very important for adolescent in the beginning of their adolescent year to increase their take on iron based on their nutrition level, because adolescent year is vulnerable in having the disruption in their menstruation. They who have this disruption will likely to have lack of iron, especially if the reserve for iron and the consumption of iron cannot fulfill the outtake of iron from the bleeding when they have their period.

Most of the respondents $(86.8 \%)$ are categorized using more than 6 menstrual pads in one of their menstrual cycle. It is in line with the study by Gokyildiz (2013) about the effect of outrageous bleeding, which said that adolescent who bleed above normal (above $80 \mathrm{~mL} /$ cycle) are only $12 \%$. In many studies conducted by some countries in the world, WHO identifies 
that the prevalence of outrageous bleeding is around $8-27 \%$.

The gap between menarche and the study towards the respondents is 3,49 years in average with the deviation standard reached 2,12 years. The more they have their menstruation, the bigger they having risk in getting anemia, based on the study by Sekhar et al., (2017) about the relations between menarche and anemia, which stated that the range between menarche and the study more than 3 years is one of the risk factors of the iron deficiency which identified between big samples, representing the women who are still in their fertile age and they are not anemic (16).

Here in this study, $78.9 \%$ of the respondents are not consuming tea and coffee during their meals. Tea and coffee are consumed by the respondents in school during break. This result is in line with the study by Riyanto (2017) in Tuma'ninah Yasin Boarding School in Kota Metro Lampung where most of the respondents $(84.1 \%)$ are not consuming tea during their meals.

Quantitatively, the consumption of vitamin $\mathrm{C}$ of the respondents in this study $(78.9 \%)$ is still lacking or below $80 \%$ AKG. It is in line with the study by Akib (2017) where most of the respondents $(95 \%)$ are having vitamin $\mathrm{C}$ less than $80 \%$ AKG. While on the other hand, based on the study by Damayanti Siallagan et al (2016) shows that every increase of $1 \mathrm{mg}$ of the vitamin $\mathrm{C}$ can help increasing the level of $\mathrm{Hb}$ by 0.002 $\mathrm{g} / \mathrm{dL}$.

Most of respondent in this study $(81,6 \%)$, have less consumption for animal-based protein. The lack of consumption of animal-based protein is likely to be affected by the principle of living in humble way and refraining themselves from unnecessary needs or commonly known as tirakat / zuhud.
These ways of living are still practiced in boarding schools. Animal-based protein has a high value of socialeconomy from the students' point of view, so reducing the consumption of those protein is considered living in modesty or tirakat / zuhud.

After supplements are given, $60.5 \%$ of the respondents changed into not anemic. The increased level of hemoglobin in this study is higher compared to the study by Susanti, et al (2016) (19) after being given supplements for 14 weeks. The increased level of hemoglobin happened after the respondents are given supplements for 8 weeks, likely because of the high consumption level of IFA tablet supplements used in this study and also the regulation of iron control in the body.

The result of this study reveals that significantly, first treament (once in a week for 8 weeks) and second treatment (once in a week added by daily dose in their menstrual cycle for 8 weeks) can increase the hemoglobin level of the respondents. This result is in line with the study by Februhartanty (2002), for 16 weeks in female adolescent in Kupang, there are some significant differences of the hemoglobin level, after supplement for iron tablets, both from the group which has the weekly supplement and group which has the 4-day supplement during their menstrual cycle (20).

The significant increasing level of hemoglobin in both groups cannot be separated from the anemic status of the respondents. There are many studies which reveal that someone who is anemic is more responsive in the changing of hemoglobin, it is linked by the process of iron regulation of iron in the body, when someone who is lacking from iron, then they will likely have increased level of iron. 
There is no significant difference in the average number of increased in hemoglobin in both treatment groups. The result of this study is different with the study by Februhartanty et al (2002) where there is significant difference between supplements that given weekly plus the supplement given for 4 days during their period for 16 weeks. The difference of this results is probably caused by the difference of duration of the supplements given, where this study has shorter duration compared to the previous study.

The result of this study confirmed the results of other studies that the 8-week supplement can increase the level of hemoglobin. However, it needs further study to make it clearer whether the supplements given for 8 weeks can increase the reserve of iron in the body or not.

\section{Conclusion}

The female students in Miftahul Huda Al Azhar Langgensari Banjar Boarding School are having problems related to anemia, and it is a big problem for public health with the prevalence of $52.25 \%$.

The result for bivariate analysis shows that there is an increased level of hemoglobin in both groups after being intervened for 8 weeks, compared to the previous situation. However, the result of multivariate analysis of the treatment 2 group gives slightly higher level of hemoglobin $(0.061 \mathrm{~g} / \mathrm{dL})$ compared to treatment 1 group, but this increase was not that different statistically. It can be drawn that the weekly supplement or once-in-a-week supplement with high level of adherence is sufficient to increase the level of hemoglobin. But the absence of a difference in the level of hemoglobin does not necessarily mean that there is no difference in the level of iron reserve in the body.
The result of this study supports the programs of WHO and the government that the supplements given once in a week is sufficient to increase the level of hemoglobin. Iron Suplementation in this study showed $100 \%$ adherence, to both intervervention group, wich was probably due to effective education that was carried out before suplementation and support from the leadership of boarding school. Therefore, to optimizing iron suplementation in boarding school these two things must be considered. However, there are some differences, the treatment 2 group has better increase level of $\mathrm{Hb}$, which we are not sure whether it is caused by the short duration of the study? Therefore, it is suggested that further study is conducted with longer duration and also examining the reserve of iron in the body.

\section{Acknowledgment}

Gratitude is conveyed to the Miftahul Huda Al Azhar Boarding School for giving permission and facilitate the researchers to carry out this study.

\section{References}

1. Raveendran A, Shiji P, Qassabi FS Al. Iron deficiency anemia: An update. BMH Med J. 2019;6(4):116-30.

2. Wulandari, Catur Leni; Fitriasih Y. Pentingnya Suplemen Tablet Besi Bagi Peningagkatan Kadar Hemoglobin Pada Remaja Putri. J Sultan Agung. 2014;52 (133).

3. Brannon PM, Taylor CL. Iron supplementation during pregnancy and infancy: Uncertainties and implications for research and policy. Nutr J. 2017;9(12):1-17.

4. Sumarlan ES, Windiastuti E, Gunardi H. Iron Status, Prevalence and Risk 
Factors of Iron Deficiency Anemia Among 12- to 15-Year-Old Adolescent Girls from Different Socioeconomic Status in Indonesia. Makara J Heal Res. 2018;22(1):46-52.

5. Santos CLDA, Akerman M, Faccenda O, Martins LC, Reato L de FN. Anemia Deficiency During Pubertal Growth Spurt. J Hum Growth Dev. 2012;22(3):341.

6. Dambal S, Panneerselvam S. Anemia In Adolescent Girls. Asian Pacific J Nurs. 2018;5(1):7-8.

7. Kemenkes. pedoman pencegahan dan penanggulangan anemia pada remaja putri dan wanita usia subur. jakarta:

Kemenkes; 2016.

8. Mengistu G, Azage M, Gutema H. Iron Deficiency Anemia among In-School Adolescent Girls in Rural Area of Bahir Dar City Administration, North West Ethiopia. Anemia. 2019;2019:19.

9. Hamidiyah A, Rohmani L, Zahro N. Faktor Determinan Anemia Santri Putri. J Ilm Kebidanan. 2019 Feb $1 ; 6: 64-72$.

10. Hibattino DR, Bardosono S. Prevalensi Anemia Dan Hubungannya Dengan Asupan Zat Besi Pada Santri Usia 1318 Tahun Di Pesantren X Tahun 2011. Fk Ui. 2014;

11. Yunitasari E, Rachmawati PD, Lestari DIN. Effort to Prevent Anaemia During Menstruation among Female Adolescent in Islamic Boarding School. J Ners. 2019;14(1):28.

12. Shara F El, Wahid I, Semiarti R. Hubungan Status Gizi dengan Kejadian Anemia pada Remaja Putri di SMAN 2 Sawahlunto Tahun 2014. J Kesehat Andalas. 2017;6(1):202-7.

13. Food and Nutrition Technical Assistance III Project (FANTA).
Nutrition Assessment, Counseling, and Support (NACS): A User's GuideModule 2: Nutrition Assessment and Classification, Version 2. Washington DC: FHI 360/FANTA; 2016.

14. Arumsari E. Faktor Resiko Anemia Pada Remaja Putri Peserta Program Pencegahan dan Penanggulangan Anemia Gizi Besi (PPAGB) si Kota Bekasi. Institut Pertanian Bogor; 2008.

15. Gokyildiz S, Aslan E, Beji NK, Mecdi $M$. The Effects of Menorrhagia on Women's Quality of Life: A CaseControl Study. J ISRN Obstet Gynecol. 2013;2013(2010):1-7.

16. Sekhar DL, Murray-Kolb LE, Kunselman AR, Weisman CS, Paul IM. Association Between Menarche and Iron Deficiency in Non-Anemic Young Women. J PLoS ONE. 2017;12(5):1-11.

17. Riyanto R, Lestari GI. Kejadian Anemia Berdasarkan Status Gizi , Pengetahuan dan Pola Minum Teh pada Remaja Putri di Pondok Pesantren. J Kesehat Metro Sai Wawai. 2017;10(2):83-9.

18. Akib A, Sumarmi S. Kebiasaan Makan Remaja Putri yang Berhubungan dengan Anemia : Kajian Positive Deviance. Amerta Nutr. 2017;1(2):105-16.

19. Susanti Y, Briawan D, Martianto D. Suplementasi Besi Mingguan Meningkatkan Hemoglobin Sama Efektif dengan Kombinasi Mingguan dan Harian pada Remaja Putri. J Gizi dan Pangan. 2016;11(1):28.

20. Februhartanty J, Dillon D, Khusun H. Will iron supplementation given during menstruation improve iron status better than weekly supplementation? Asia Pac J Clin Nutr. 2002;11(1):36-41. 